\title{
Methane and Inflammation - A Review (Fight Fire with Fire)
}

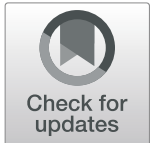

\author{
Marietta Zita Poles ${ }^{\dagger}$, László Juhász ${ }^{\dagger}$ and Mihály Boros ${ }^{*}$ (i)
}

\author{
* Correspondence: boros.mihaly@ \\ med.u-szeged.hu \\ Metallica, 1984; Title of a song from \\ the 'Ride the Lightning' album. \\ 'Marietta Zita Poles and László \\ Juhász contributed equally to this \\ work. \\ Institute of Surgical Research, \\ University of Szeged, Pulz u. 1., \\ Szeged H-6724, Hungary
}

\begin{abstract}
Mammalian methanogenesis is regarded as an indicator of carbohydrate fermentation by anaerobic gastrointestinal flora. Once generated by microbes or released by a nonbacterial process, methane is generally considered to be biologically inactive. However, recent studies have provided evidence for methane bioactivity in various in vivo settings. The administration of methane either in gas form or solutions has been shown to have anti-inflammatory and neuroprotective effects in an array of experimental conditions, such as ischemia/reperfusion, endotoxemia and sepsis. It has also been demonstrated that exogenous methane influences the key regulatory mechanisms and cellular signalling pathways involved in oxidative and nitrosative stress responses. This review offers an insight into the latest findings on the multi-faceted organ protective activity of exogenous methane treatments with special emphasis on its versatile effects demonstrated in sepsis models.
\end{abstract}

Keywords: Methanogenesis, Exogenous methane, Ischemia/reperfusion, Sepsis, Bioactivity

\section{Background}

The human body uses and produces several gases. Nitric oxide (NO), carbon monoxide (CO) and hydrogen sulphide $\left(\mathrm{H}_{2} \mathrm{~S}\right)$ - once considered to be toxic air pollutants-play a vital biochemical modulator role in living tissues. These small, volatile, available and biologically effective molecules are classified as 'gasotransmitters', which means that they take part in cellular communications. Methane $\left(\mathrm{CH}_{4}\right)$ is also part of the gaseous environment which maintains the aerobic metabolism within the living system. If we discuss the available literature data on the generation and biological effects of $\mathrm{CH}_{4}$, the current evidence does not fully support the gasotransmitter concept, but it does support the notion that $\mathrm{CH}_{4}$ is bioactive. Several clinical studies have demonstrated that endogenous $\mathrm{CH}_{4}$ can modulate the signalling mechanisms of the enteric nervous system; in addition, exogenous $\mathrm{CH}_{4}$ has been proved to protect against organ damage in numerous experimental models associated with inflammation and/or ischemia/reperfusion (I/R) syndromes [5]. We briefly summarise the available data on the relationship between inflammatory activation and $\mathrm{CH}_{4}$ administrations with special emphasis on the possible mechanism of action. Papers that directly monitored sepsis- or endotoxinlinked organ dysfunction were then considered to illustrate the relationship between $\mathrm{CH}_{4}$ treatments and the effect on sepsis-related end organ dysfunction (Table 1). 
Table 1 Summary of in vivo studies using $\mathrm{CH}_{4}$ that also monitored sepsis/LPS/surgery-induced organ dysfunction and other parameters of tissue damage

\begin{tabular}{|c|c|c|c|}
\hline Reference & $\begin{array}{l}\text { Experimental model/ } / \mathrm{CH}_{4} \\
\text { administration route }\end{array}$ & $\begin{array}{l}\text { Target } \\
\text { organ }\end{array}$ & Reported effects/main findings \\
\hline $\begin{array}{l}\text { Zhang X } \\
\text { et al. [56] }\end{array}$ & $\begin{array}{l}\text { Mouse + LPS } \\
\text { Rat }+E . \text { coli } \\
\text { Mouse + DSS } \\
\text { MRS ( } 16 \mathrm{ml} / \mathrm{kg} \text { ip) pre- } \\
\text { treatment }\end{array}$ & $\begin{array}{l}\text { Colon } \\
\text { Immune } \\
\text { organs }\end{array}$ & $\begin{array}{l}\text { Suppressed activation of NF-KB /MAPKs } \\
\text { Increased survival } \\
\text { Enhancement of IL-10 release }\end{array}$ \\
\hline $\begin{array}{l}\text { Sun A et al. } \\
\text { [38] }\end{array}$ & $\begin{array}{l}\text { Rat }+ \text { LPS } \\
\text { MRS }(2 \mathrm{ml} / \mathrm{kg} \text { and } 20 \mathrm{ml} / \mathrm{kg}) \\
\text { pre-treatments }\end{array}$ & Lung & $\begin{array}{l}\text { Reduction of acute lung injury } \\
\text { Prolonged survival }\end{array}$ \\
\hline $\begin{array}{l}\text { Li Z et al. } \\
{[23]}\end{array}$ & $\begin{array}{l}\text { Mouse }+ \text { CLP } \\
\text { MRS }(10 \mathrm{ml} / \mathrm{kg} \text { ip) post- } \\
\text { treatment }\end{array}$ & Liver & Reduction of sepsis-induced acute liver injury \\
\hline $\begin{array}{l}\text { Jia Y et al. } \\
{[18]}\end{array}$ & $\begin{array}{l}\text { Mouse }+ \text { CLP } \\
\text { MRS }(10 \mathrm{ml} / \mathrm{kg} \text { ip) post- } \\
\text { treatment }\end{array}$ & Kidney & Reduction of sepsis-induced acute kidney injury \\
\hline $\begin{array}{l}\text { Li Z et al. } \\
{[22]}\end{array}$ & $\begin{array}{l}\text { Mouse }+ \text { CLP } \\
\text { MRS post-treatment }\end{array}$ & $\begin{array}{l}\text { Lung } \\
\text { Intestines }\end{array}$ & $\begin{array}{l}\text { Inhibition of NOD-like receptor protein 3-mediated } \\
\text { pyroptosis in vivo and in vitro }\end{array}$ \\
\hline $\begin{array}{l}\text { Bari G et al. } \\
{[2]}\end{array}$ & $\begin{array}{l}\text { Pig }+\mathrm{ECC} \\
\text { Inhalation of } 2.5 \% \mathrm{v} / \mathrm{vCH}_{4}- \\
\text { normoxic air }\end{array}$ & Kidney & $\begin{array}{l}\text { Higher renal blood flow during extracorporeal } \\
\text { circulation }\end{array}$ \\
\hline $\begin{array}{l}\text { Zhang D } \\
\text { et al. [58] }\end{array}$ & $\begin{array}{l}\text { Mouse }+ \text { abdominal surgery } \\
\text { MRS }(16 \mathrm{ml} / \mathrm{kg} \text { ip) post- } \\
\text { treatment }\end{array}$ & Brain & $\begin{array}{l}\text { Reduction of postoperative cognitive dysfunction and } \\
\text { microglial activation }\end{array}$ \\
\hline
\end{tabular}

$C L P$, cecal ligation and puncture; DSS, dextran sodium sulfate; $E C C$, extracorporeal circulation; IL-10, interleukin 10; LPS, lipopolysaccharide; MAPKs, mitogen-activated protein kinase; $M R S$, methane-rich saline; NF-KB, nuclear factor-KB

\section{$\mathrm{CH}_{4}$ : a brief overview}

$\mathrm{CH}_{4}$ is an intrinsically non-toxic, combustible gas which forms explosive mixtures with air at concentrations between 5\% (lower explosive limit) and 15\% (upper explosive limit) at room temperature. In humans, large amounts of $\mathrm{CH}_{4}$ can be produced by carbohydrate fermentation in the gastrointestinal (GI) tract through the metabolism of methanogenic microorganisms. The catalysing enzyme of this pathway is methyl coenzyme $M$ reductase, while the microorganisms are obligate anaerobic Archae $[9,20,21,34,49]$.

It should be added that relatively little is known about the in vivo roles of commensal methanogens in GI physiology because it is impossible to study or culture these microorganisms together with oxygen-requiring aerobic cells in conventional ways. The actual level of endogenous $\mathrm{CH}_{4}$ generation in the human body is still an open question. In general terms, about one-third of healthy adults emit gaseous $\mathrm{CH}_{4}$ identified with conventional breath testing, but a recent study using stable carbon isotopes and high-precision measurements provided evidence that exhaled $\mathrm{CH}_{4}$ levels were always above inhaled $\mathrm{CH}_{4}$ concentration [20]. Significant $\mathrm{CH}_{4}$ release was also demonstrated in previously non- $\mathrm{CH}_{4}$ producer volunteers after high ethanol intake [43]. Furthermore, in vitro and in vivo studies have revealed the possibility of non-microbial $\mathrm{CH}_{4}$ formation in mitochondria [29, 30] and eukaryotic cells, especially under hypoxic stress stimuli [14, 15, 44-46, 48]. Today, the sum of evidence suggests that a variable amount of excreted $\mathrm{CH}_{4}$ in the breath of mammals is possibly linked to non-archaeal processes $[6,42]$.

Another important issue is that due to its physico-chemical properties, intraluminal $\mathrm{CH}_{4}$ can traverse the GI mucosa and enter the splanchnic circulation freely. When 
reaching the lungs, the transported $\mathrm{CH}_{4}$ is partially released into the breath if the partial pressure is higher than that in the atmosphere, where it is normally about 1.8 parts per million volume (ppmv). Therefore, exhaled $\mathrm{CH}_{4}$ levels will change in relation to intestinal perfusion alterations, and variations in breath $\mathrm{CH}_{4}$ output may thus be related to the flow conditions of the mesenteric microcirculation as well [40].

\section{Endogenous $\mathrm{CH}_{4}$}

Elevated breath $\mathrm{CH}_{4}$ concentrations have been traditionally linked to numerous GI health conditions, such as sugar malabsorption, small intestinal bacterial overgrowth or irritable bowel syndrome $[7,10,13,33,41]$. Further data suggest that endogenously produced $\mathrm{CH}_{4}$ can influence mammalian metabolism and thus energy homeostasis [5]. More importantly, higher $\mathrm{CH}_{4}$ concentrations in the GI tract can significantly slow transit time, while increasing the number of muscle contractions [17, 31]. It has been suggested that by slowing down the transit, the time for nutrient absorption is lengthened, which, together with boosted levels of methanogenic microorganisms in the intestines, could lead to an increased weight gain process and thus the development of obesity [3]. Indeed, a significantly higher ratio of $\mathrm{H}_{2}$-utilizing methanogen Archaea is associated with obesity $[26,27,55]$.

\section{Effects of exogenous $\mathrm{CH}_{4}$}

It should be noted that a shift in the energy balance may alter the inflammatory status as well. In this line, in a rat model of endurance exercise, treadmill running induced inflammatory activation, including leukocyte accumulation (evidenced by myeloperoxidase (MPO) activity, raised plasma levels of interleukins IL-1 $\beta$, IL-6, IL-10 and tumour necrosis factor alpha (TNF- $\alpha$ )), while exogenous $\mathrm{CH}_{4}$ administration prolonged the running time and normalised the changes in blood lactate and glucose and the parameters of pro-inflammatory activation in the animals [52].

Indeed, it has been shown that exogenous $\mathrm{CH}_{4}$ efficiently influences many aspects of inflammatory pathologies $[5,6]$. After the first study using a model of intestinal $I / R$, several series of analyses demonstrated that $\mathrm{CH}_{4}$-containing normoxic artificial air $\left(2.2-2.5 \mathrm{v} / \mathrm{v} \% \mathrm{CH}_{4}\right)$ has anti-inflammatory effects in I/R injuries with decreasing oxidative and nitrosative stress levels $[4,29,32] . \mathrm{CH}_{4}$ inhalation improved mitochondrial function by preserving the control levels of basal respiration and lowering cytochrome c activity [37]. Serosal microcirculation, the structure of small intestinal mucosa and the epithelial barrier function were also preserved by $\mathrm{CH}_{4}$ inhalation in a mesenteric I/ $\mathrm{R}$ model [29]. In a recent study, where the nitrergic neuron numbers were characterised in adjacent intestinal segments before and after the occlusion of the superior mesenteric artery, exogenous $\mathrm{CH}_{4}$ inhalation significantly suppressed nitrotyrosine formation at all intestinal sites and protected the nitrergic neuron population [32]. Nitrotyrosine formation has been significantly suppressed by raising the $\mathrm{CH}_{4}$ input prior to stress induction in other animal models as well. In this line, exogenous $\mathrm{CH}_{4}$ lowered the malondialdehyde (MDA) and TNF- $\alpha$ levels, increased protein kinase B phosphorylation and hemoxygenase-1 (HO-1) expression, and significantly reduced neuronal deficit in a cerebral I/R model [57]. 


\section{$\mathrm{CH}_{4}$-enriched saline}

$\mathrm{CH}_{4}$ can be administered in supersaturated methane-rich saline (MRS) solution as well (using 0.4 $\mathrm{MPa}$ pressure for $3 \mathrm{~h}$ ). In this case, the concentration of $\mathrm{CH}_{4}$ does not drop

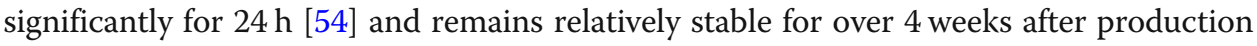
[8]. Using MRS, Ye et al. [54] first demonstrated that the plasma alanine aminotransferase (ALT) and aspartate aminotransferase (AST) levels were dose-dependently decreased after liver I/R. MRS also alleviated inflammation by reducing the elevated serum levels of interleukin-6 (IL-6), TNF- $\alpha$, interleukin-1 $\beta$ (IL-1 $\beta$ ) and interferon- $\gamma$ $(\mathrm{IFN}-\gamma)$ and activated nuclear factor $-\mathrm{kB}(\mathrm{NF}-\mathrm{kB})$ and mitogen-activated protein kinases (MAPK) both in concanavalin A-induced autoimmune hepatitis [16] and in carbon tetrachloride-induced liver injury [53]. In the latter case, MRS reduced the activation of chemokine ligand 1 (CXCL1), intercellular adhesion molecule-1 (ICAM-1) and MPO activity as well, while serum ALT and AST levels returned to control levels.

Recently, Wang et al. [47] demonstrated that MRS treatment is able to reduce the spleen weight, the disease activity index, the ulcer area and the histology score in acetic acid-treated mice with colitis. In this experimental series, MRS alleviated the inflammatory activation through reduced serum TNF- $\alpha$ and IL- 6 and raised IL10 levels. Oxidative stress with lowered tissue MDA levels and myeloperoxidase (MPO) activity and increased superoxide dismutase (SOD) and glutathione transferase (GSH) activity was reduced almost as effectively as after salazosulfapyridine treatment. Similar results have been presented in an acute pancreatitis model. The intraperitoneally applied MRS improved the tissue damage scores, exerted potent anti-apoptotic effects, inhibited the elevation of inflammatory cytokines (TNF- $\alpha$, IL-6 and IFN- $\gamma$ ), elevated IL-10 levels, decreased tissue MPO activity and preserved SOD activity [51]. In a renal $\mathrm{I} / \mathrm{R}$ model, MRS induced higher catalase (CAT) and SOD activity with diminished tissue MPO activity, MDA and 8-hydroxy-2'-deoxyguanosine (8-OHdG) levels, a lower rate of apoptosis was detected in the tissues, and suppressed blood urea nitrogen and creatinine, serum IL- 6 and TNF- $\alpha$ levels were present. Again, this approach increased IL-10 concentration and decreased the number of $\mathrm{F} 4 / 80^{+}$macrophages in the renal tissue as well [28].

The anti-apoptotic effects of $\mathrm{CH}_{4}$ were first described in skin and liver I/R models $[36,54]$. The authors have shown that MRS protects the transplanted skin flaps by reducing the leukocyte infiltration and lowering the apoptotic cell count, increases the expression of the anti-apoptotic B cell leukaemia/lymphoma-2 (Bcl-2) and attenuates the pro-apoptotic protein Bcl-2-associated X protein (Bax), the expression of pASK-1, p-JNK, and caspase-3 activity [36].

In a clinically relevant rat model, MRS treatment improved the cardiac function and prevented the formation of myocardial fibrosis in the long run 4 weeks after myocardial infarction. $\mathrm{CH}_{4}$ treatment reduced the level of myocardial necroenzymes, increased tissue SOD activity and GSH content, and lowered MPO activity, MDA and 8-OHdG levels, and xanthine oxidoreductase (XOR) expression. Again, the treatment decreased the number of apoptotic cells in addition to diminishing the expression of caspase-3 and caspase-9, and the Bax/Bcl-2 ratio [8].

There is also a growing amount of data on the neuroprotective properties of $\mathrm{CH}_{4}$. In a CO toxicity model, Fan et al. [12] demonstrated that MRS was protective against learning deficit, and Shen et al. [35] showed that MRS treatment raised the number of 
Nissl-stained cells and the potency to restore the CA1 region and cortex. Both research teams showed that MRS decreased tissue MDA, 3-nitrotyrosine and 8-OHdG levels, and plasma TNF- $\alpha$ and IL-1 $\beta$ levels, while increasing plasma IL- 6 content and tissue SOD activity $[12,35]$. MRS treatment reversed the changes in the thickness of the inner nuclear layer and the inner plexiform layer after diabetic retinopathy [50] and suppressed the reduction of retinal thickness after I/R [24]. In addition, MRS inhibited ganglion cell loss [24, 44-46, 50], improved the blood-retina barrier function [50], reduced visual dysfunction [24, 44-46], and lowered TNF- $\alpha$ - and IL-1 $\beta$-positive cell numbers, and expression of VEGF and GFAP [50]. MRS decreased the overexpression of a mitochondrial biogenesis marker (PGC1- $\alpha$ ) and restored citrate synthase activity, thus boosting ATP levels [44-46]. It also enhanced the upregulation of Bcl-2 and reduced the upregulation of Bax, caspase- 3 and caspase-9, and cut oxidative stress levels by significantly suppressing 8-OHdG, 4-hydroxy-2-nonenal (4-HNE) and MDA levels, thus increasing SOD, CAT and glutathione peroxidase (GPx) activity [24]. In a spinal cord injury model, MRS treatment improved the Basso, Beattie and Bresnahan score over time, lowered microglial activation and inflammatory cell infiltration, raised tissue SOD activity and reduced MDA, TNF- $\alpha$, IL-1 $\beta$ and IL-6 levels [44-46]. In a very similar spinal cord I/R study, MRS improved neurological damage, preserved the bloodspinal cord barrier, reduced oedema formation and leukocyte infiltration, and boosted SOD, CAT activity and GSH levels, while decreasing MDA, 8-OHdG and 3nitrotyrosine levels. It also lowered the apoptotic cell number, caspase-3 and caspase- 9 levels, and cytochrome c translocation into the cytoplasm, the mRNA and content of TNF- $\alpha$, IL-1 $\beta$, CXCL1 and ICAM-1 and the metalloproteinase MMP-9, while increasing the expression of the tight junction proteins claudin-5, occludin and ZO-1 [44-46]. The suppressed microglia and astrocyte activation, together with lowered CD3-positive $\mathrm{T}$ cell infiltration, was demonstrated in an arthritis model as well [59].

\section{Possible mechanisms of action}

Due to its apolar properties, $\mathrm{CH}_{4}$ can be dissolved in cell membranes; it may thus be able to influence the physiochemical condition of the phospholipid bilayer [11]. Similar to halothane, which can influence the G-protein-mediated signalling pathways, $\mathrm{CH}_{4}$ is able to affect the function of transmembrane proteins, enzymes and ion channels [8]. Indeed, several studies have demonstrated the modulator effect of $\mathrm{CH}_{4}$ on cell-cell junctions and plasma membrane integrity under oxido-reductive stress conditions. Nevertheless, it has also been shown that $\mathrm{CH}_{4}$ can influence XOR activity and the isoform ratio of XOR; this facilitates its conversion into the xanthine dehydrogenase isoform, which then produces less reactive oxygen species (ROS) [4, 32]. XOR is not a transmembrane protein; thus, other possibilities, such as changing the hydrophobic environment around the FAD site, should be taken into account to understand the mechanism of $\mathrm{CH}_{4}$ action.

Interestingly, $\mathrm{CH}_{4}$ accumulation may directly influence intracellular signalling reactions, leading to anti-inflammatory responses via master switches, such as nuclear factor erythroid 2-related factor 2 (Nrf2)/Kelch-like ECH-associated protein 1 (Keap1) or $\mathrm{NF}-\mathrm{kB}$ [56]. $\mathrm{CH}_{4}$ seems to have effects on the phosphoinositide 3-kinase (PI3K) pathway by facilitating the activation of Akt protein, thus increasing the expression of the 
HO-1 enzyme and promoting its anti-oxidative effects [57]. Moreover, also via the PI3K/Akt pathway, $\mathrm{CH}_{4}$ is able to influence the expression of the anti-inflammatory

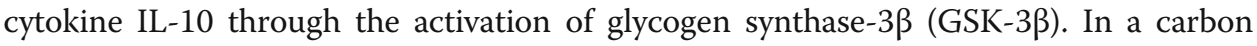
tetrachloride-derived liver inflammation model, Yao et al. [53] blocked GSK-3 $\beta$ with wortmannin and pre-treated mice with anti-IL-10 antibody, which abolished the beneficial effects of MRS and raised the levels of phosphorylated NF- $\mathrm{KB}$ and MAPK proteins supporting the involvement of these pathways in the anti-inflammatory effects of $\mathrm{CH}_{4}$. In an acetic acid-induced ulcerative colitis model, MRS also proved its protective effects by blocking the expression of Toll-like receptor 4 (TLR4) and myeloid differentiation primary response 88 protein (MyD88) and attenuating the expression levels of $\mathrm{p}$ NF- $\mathrm{kB}, \mathrm{p} 65, \mathrm{p}-\mathrm{JNK}, \mathrm{p}-\mathrm{ERK}$ and $\mathrm{p}-\mathrm{P} 38$. On the other hand, $\mathrm{CH}_{4}$ could promote the expression of IL-10, Janus kinase 1 (JAK1), and signal transducer and activator of transcription 3 (STAT3), thus facilitating the anti-inflammatory response [47]. In another study, Wang et al. showed that MRS treatment facilitated the time-dependent nuclear translocation of Nrf2 in neurons, microglia and astrocytes after spinal cord injury. In addition, expression of the Nrf2 inhibitor Keap1 protein was inhibited and NF- $\mathrm{kB}$ translocation was blocked via this pathway [44-46].

\section{The effects of $\mathrm{CH}_{4}$ in endotoxemia and sepsis}

The effects of exogenous $\mathrm{CH}_{4}$ were tested in sepsis models as well, and it seems that $\mathrm{CH}_{4}$-mediated protection involves a triad of anti-inflammatory, anti-oxidative and antiapoptotic actions (the mechanisms of $\mathrm{CH}_{4}$-mediated protection in experimental models of sepsis and endotoxemia are summarised in Fig. 1). Along with the 'anti-effects', antipyroptotic activity (a form of programmed cell death that occurs during infection) was recently also reported in lung and intestinal tissues in mice [22]. As the first steps of pyroptosis, NOD-like receptor protein 3 (NLRP3) inflammasome formation activates caspase-1, which in turn further drives inflammation via the cleavage of pro-IL-1 $\beta$ to IL-1 $\beta$ and pro-IL-18 to IL-18. Then an effector protein (Gasdermin D) is cleaved, and it forms pores within the membrane and induces pyroptosis [39].

Most importantly, MRS administration reduced cecal ligation and puncture (CLP)-induced endoplasmic reticulum stress in the kidney through the suppression of the GRP78/ATF4/CHOP/caspase-12-mediated apoptotic pathway [18]. Similar to the findings for MRS-treated ulcerative colitis [47] or autoimmune hepatitis [16] and in carbon tetrachloride-induced liver injury [53], $\mathrm{CH}_{4}$ also attenuated the lipopolysaccharide (LPS)-induced activation of MAPKs and NF- $\mathrm{BB}$ [56]. Moreover, $\mathrm{CH}_{4}$ enhanced GSK-3 $\beta$ activation, thus leading to an increased expression of the anti-inflammatory cytokine IL-10, similar to the findings for a carbon tetrachloride-derived liver inflammation model $[53,56]$.

All of these effects could collectively contribute to reduced cellular and tissue injury (i.e. in the lungs, intestines, kidneys and liver), amelioration of organ dysfunction (e.g. enzyme markers and histopathological scores) and increased survival [18, 22, 23, 38, 56]. Indeed, the 5-day and 7-day survival rates were boosted significantly after MRS therapies $[22,56]$.

Finally, it has been demonstrated that $\mathrm{CH}_{4}$ inhalation was able to reduce the systemic inflammatory response in a clinically relevant pig model of extracorporeal circulation 


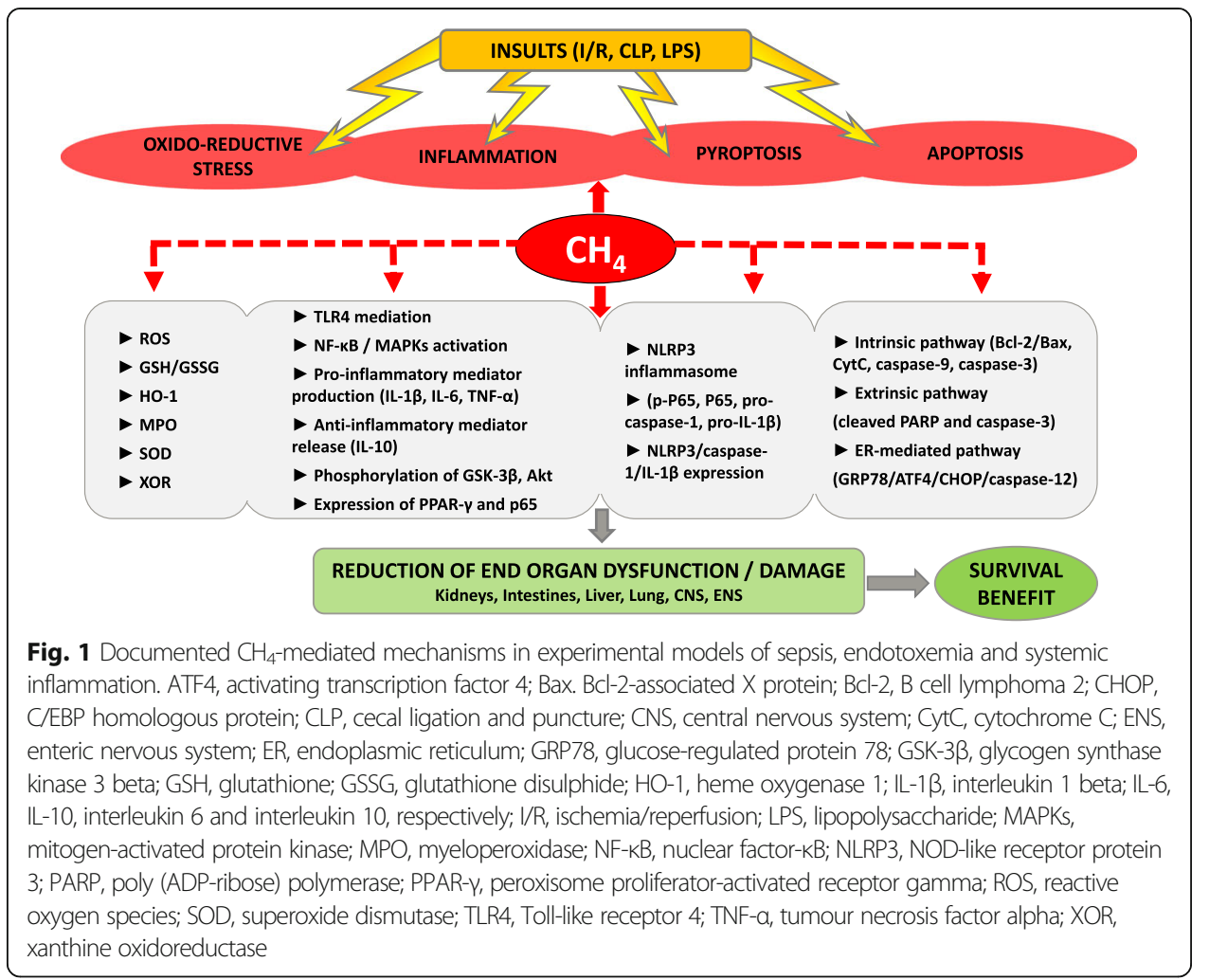

(ECC). In this study, the inotropic demand was significantly lower, the renal XOR activity was reduced, the arterial flow was significantly higher, and the hour diuresis remained in the low normal range compared with the oliguria in the animals without $\mathrm{CH}_{4}$ treatment [2].

\section{Possible side effects of $\mathrm{CH}_{4}$}

$\mathrm{CH}_{4}$ is a simple asphyxiant, meaning that it will displace oxygen in the air when present at about $14 \%$ in a restricted place. In such cases, the respiratory dysfunction is not due to the chemical specificity of the gas, but to the decreased oxygen content. Apart from $\mathrm{CH}_{4}$-induced asphyxia, there is very little known about the side effects of $\mathrm{CH}_{4}$ administration or how it may impact endogenous bacterial and non-bacterial productions. In a case report, Jo et al. [19] reported on $\mathrm{CH}_{4}$-caused acute respiratory distress, but it remained unclear whether this was related to the reduced oxygen content or due to the direct gas effect within the lung tissue. Similarly, the harmful effects of inhaled $\mathrm{CH}_{4}$ could not be proven by the study of Manning et al. [25], where lower $\mathrm{O}_{2}$ and extremely high $\mathrm{CO}_{2}$ levels were present together with the higher concentration of $\mathrm{CH}_{4}$. Data on

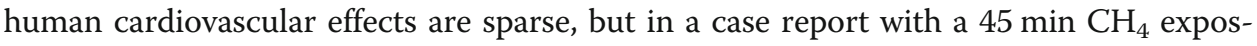
ure, the unconscious patient had spontaneous breathing with an arterial $\mathrm{pH}$ value of 7.26 and made a full recovery later [1].

\section{Conclusion}

The review of the available literature argues in favour of $\mathrm{CH}_{4}$ as a bioactive, therapeutic gas: exogenous $\mathrm{CH}_{4}$ improves cellular/organ function and increases survival in 
experimental models of inflammation, I/R, sepsis and endotoxemia. Future investigations should provide additional evidence for the efficacy of $\mathrm{CH}_{4}$-based treatments in other types of infectious disease models, filling the missing gaps in the still not fully understood cellular signalling pathways and the mechanism of action of $\mathrm{CH}_{4}$.

\section{Abbreviations}

8-OHdG: 8-hydroxy-2'-deoxyguanosine; ALT: Alanine aminotransferase; AST: Aspartate aminotransferase; Bax: BCl-2associated X protein; BCl-2: B cell leukaemia/lymphoma-2 protein; CAT: Catalase; $\mathrm{CH}_{4}$ : Methane; CLP: Cecal ligation and puncture; CO: Carbon monoxide; CXCL1: Chemokine ligand 1; ECC: Extracorporeal circulation; Gl: Gastrointestinal;

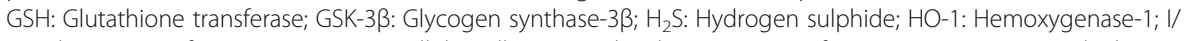
R: Ischemia/reperfusion; ICAM-1: Intercellular adhesion molecule-1; IFN-Y: Interferon gamma; IL-10: Interleukin 10; IL1ß: Interleukin 1 beta; IL-6: Interleukin 6; Keap1: Kelch-like ECH-associated protein 1; LPS: Lipopolysaccharide; MAPK: Mitogen-activated protein kinase; MDA: Malondialdehyde; MPO: Myeloperoxidase; MRS: Methane-rich saline; NFKB: Nuclear factor-kB; NLRP3: NOD-like receptor protein 3; NO: Nitric oxide; Nrf2: Nuclear factor erythroid 2-related factor 2; ppmv: Parts per million volume; SOD: Superoxide dismutase; TNF-a: Tumour necrosis factor alpha; XOR: Xanthine oxidoreductase

\section{Acknowledgements}

Not applicable.

\section{Authors' contributions}

$M P$ and $L J$ drafted the article. MB contributed to correcting and proofreading the article. MP and $L J$ contributed equally. All the authors read and approved the final manuscript.

\section{Funding}

Supported by the Hungarian Research Foundation (NKFI K120232).

\section{Availability of data and materials}

The datasets generated and/or analysed during the current study are available in PubMed.

\section{Ethics approval and consent to participate}

Not applicable.

\section{Consent for publication}

Not applicable.

\section{Competing interests}

The authors declare that they have no competing interests.

Received: 22 August 2019 Accepted: 24 October 2019

Published online: 05 December 2019

References

1. Baldursdottir S, Sigvaldason K, Karason S, Valsson F, Sigurdsson GH (2010) Induced hypothermia in comatose survivors of asphyxia: a case series of 14 consecutive cases. Acta Anaesthesiol Scand 54(7):821

2. Bari G, Érces D, Varga G, Szücs S, Varga Z, Bogáts G, Boros M (2019) Methane inhalation reduces the systemic inflammatory response in a large animal model of extracorporeal circulation. Eur J Cardiothorac Surg 56(1):135-142. https://doi.org/10.1093/ejcts/ezy453

3. Basseri RJ, Basseri B, Pimentel M, Chong K, Youdim A, Low K, Hwang L, Soffer E, Chang C, Mathur R (2012) Intestinal methane production in obese individuals is associated with a higher body mass index. Gastroenterol Hepatol 8:22-28

4. Boros M, Ghyczy M, Érces D, Varga G, Tőkés T, Kupai K, Torday C, Kaszaki J (2012) The anti-inflammatory effects of methane. Crit Care Med 40:1269-1278. https://doi.org/10.1097/CCM.0b013e31823dae05

5. Boros M, Keppler F (2018) Production and signalling of methane. In: Wang R (ed) Gasotransmitters, Royal Society of Chemistry, pp 192-234. https://doi.org/10.1039/9781788013000

6. Boros M, Tuboly E, Mészáros A, Amann A (2015) The role of methane in mammalian physiology - is it a gasotransmitter? J Breath Res 9(1):014001. https://doi.org/10.1088/1752-7155/9/1/014001

7. Chatterjee S, Park S, Low K, Kong Y, Pimentel M (2007) The degree of breath methane production in IBS correlates with the severity of constipation. Am J Gastroenterol 102:837-841

8. Chen O, Ye Z, Cao Z, Manaenko A, Ning K, Zhai X, Zhang R, Zhang T, Chen X, Liu W, Sun X (2016) Methane attenuates myocardial ischemia injury in rats through anti-oxidative, anti-apoptotic and anti-inflammatory actions. Free Radic Biol Med 90:1-11. https://doi.org/10.1016/j.freeradbiomed.2015.11.017

9. Conrad R, Klose M (1999) Anaerobic conversion of carbon dioxide to methane, acetate and propionate on washed rice roots. FEMS Microbiol Ecol 30:147-155

10. de Lacy Costello BPJ, Ledochowski M, Ratcliffe NM (2013) The importance of methane breath testing: a review. 7 : 024001. https://doi.org/10.1088/1752-7155/7/2/024001

11. Despa F, Berry RS (2008) Hydrophobe-water interactions: methane as a model. Biophys J 95:4241-4245. https://doi.org/ 10.1529/BIOPHYSJ.108.137216

12. Fan DF, Hu HJ, Sun Q, Lv Y, Ye ZH, Sun XJ, Pan SY (2016) Neuroprotective effects of exogenous methane in a rat model of acute carbon monoxide poisoning. Brain Res 1633:62-72. https://doi.org/10.1016/j.brainres.2015.12.019 
13. Ghoshal U, Srivastava D, Verma A, Misra A (2011) Slow transit constipation associated with excess methane production and its improvement following rifaximin therapy: a case report. J Neurogastroenterol Motil 17:185-188. https://doi.org/ 10.5056/jnm.2011.17.2.185

14. Ghyczy M, Boros M (2001) Electrophilic methyl groups present in the diet ameliorate pathological states induced by reductive and oxidative stress: a hypothesis. Br J Nutr 85:409-414

15. Ghyczy M, Torday C, Kaszaki J, Szabo A, Czobel M, Boros M (2008) Hypoxia-induced generation of methane in mitochondria and eukaryotic cells; an alternative approach to methanogenesis. Cell Physiol Biochem 21:251-258

16. He R, Wang L, Zhu J, Fei M, Bao S, Meng Y, Wang Y, Li J, Deng X (2016) Methane-rich saline protects against concanavalin A-induced autoimmune hepatitis in mice through anti-inflammatory and anti-oxidative pathways. Biochem Biophys Res Commun 470:22-28. https://doi.org/10.1016/j.bbrc.2015.12.080

17. Jahng J, Jung IS, Choi EJ, Conklin JL, Park H (2012) The effects of methane and hydrogen gases produced by enteric bacteria on ileal motility and colonic transit time. Neurogastroenterol Motil 24(185-190):e92. https://doi.org/10.1111/j. 1365-2982.2011.01819.x

18. Jia Y, Li Z, Feng Y, Cui R, Dong Y, Zhang X, Xiang X, Qu K, Liu C, Zhang J (2018) Methane-rich saline ameliorates sepsisinduced acute kidney injury through anti-inflammation, antioxidative, and antiapoptosis affects by regulating endoplasmic reticulum stress. Oxidative Med Cell Longev 2018:4756846. https://doi.org/10.1155/2018/4756846

19. Jo JY, Kwon YS, Lee JW, Park JS, Rho BH, Choi WI (2013) Acute respiratory distress due to methane inhalation. Tuberc Respir Dis (Seoul) 74:120-123

20. Keppler F, Schiller A, Ehehalt R, Greule M, Hartmann J, Polag D (2016) Stable isotope and high precision concentration measurements confirm that all humans produce and exhale methane. J Breath Res 10:016003

21. Levitt MD, Furne JK, Kuskowski M, Ruddy J (2006) Stability of human methanogenic flora over 35 years and a review of insights obtained from breath methane measurements. Clin Gastroenterol Hepatol 4:123-129

22. Li Z, Jia Y, Feng Y, Cui R, Miao R, Zhang X, Qu K, Liu C, Zhang J (2019) Methane alleviates sepsis-induced injury by inhibiting pyroptosis and apoptosis: in vivo and in vitro experiments. Aging 11:1226-1239. https://doi.org/10.18632/ aging.101831

23. Li Z, Jia Y, Feng Y, Cui R, Wang Z, Qu K, Liu C, Zhang J (2018) Methane-rich saline protects against sepsis-induced liver damage by regulating the PPAR- $/$ /NF-KB signaling pathway. Shock. https://doi.org/10.1097/SHK.0000000000001310

24. Liu L, Sun Q, Wang R, Chen Z, Wu J, Xia F, Fan XQ (2016) Methane attenuates retinal ischemia-reperfusion injury via anti-oxidative and anti-apoptotic pathways. Brain Res 1646:327-333. https://doi.org/10.1016/j.brainres.2016.05.037

25. Manning TJ, Ziminski K, Hyman A, Figueroa G, Lukash L (1981) Methane deaths? Was it the cause? Am J Forensic Med Pathol 2(4):333-336

26. Mathur R, Amichai M, Chua KS, Mirocha J, Barlow GM, Pimentel M (2013) Methane and hydrogen positivity on breath test is associated with greater body mass index and body fat. J Clin Endocrinol Metab 98:E698-E702. https://doi.org/10. 1210/jc.2012-3144

27. Mbakwa CA, Penders J, Savelkoul PH, Thijs C, Dagnelie PC, Mommers M, Arts IC (2015) Gut colonization with methanobrevibacter smithii is associated with childhood weight development. Obesity 23:2508-2516. https://doi.org/10. 1002/oby.21266

28. Meng Y, Jiang Z, Li N, Zhao Z, Cheng T, Yao Y, Wang L, Liu Y, Deng X (2018) Protective effects of methane-rich saline on renal ischemic-reperfusion injury in a mouse model. Med Sci Monit 24:7794-7801. https:/doi.org/10.12659/MSM.911156

29. Mészáros AT, Büki T, Fazekas B, Tuboly E, Horváth K, Poles MZ, Szűcs S, Varga G, Kaszaki J, Boros M (2017) Inhalation of methane preserves the epithelial barrier during ischemia and reperfusion in the rat small intestine. Surgery 161:16961709. https://doi.org/10.1016/j.surg.2016.12.040

30. Mészáros AT, Szilágyi ÁL, Juhász L, Tuboly E, Érces D, Varga G, Hartmann P (2017) Mitochondria as sources and targets of methane. Front Med 4:195. https://doi.org/10.3389/fmed.2017.00195

31. Pimentel M, Lin HC, Enayati P, van den Burg B, Lee HR, Chen JH, Park S, Kong Y, Conklin J (2006) Methane, a gas produced by enteric bacteria, slows intestinal transit and augments small intestinal contractile activity. Am J Physiol Gastrointest Liver Physiol 290:G1089-G1095

32. Poles MZ, Bódi N, Bagyánszki M, Fekete É, Mészáros AT, Varga G, Szűcs S, Nászai A, Kiss L, Kozlov AV, Boros M, Kaszaki J (2018) Reduction of nitrosative stress by methane: neuroprotection through xanthine oxidoreductase inhibition in a rat model of mesenteric ischemia-reperfusion. Free Radic Biol Med 120:160-169. https://doi.org/10.1016/j.freeradbiomed. 2018.03.024

33. Rezaie A, Buresi M, Lembo A, Lin H, McCallum R, Rao S, Schmulson M, Valdovinos M, Zakko S, Pimentel M (2017) Hydrogen and methane-based breath testing in gastrointestinal disorders: the North American Consensus. Am J Gastroenterol 112:775-784. https://doi.org/10.1038/ajg.2017.46

34. Romagnuolo J, Schiller D, Bailey RJ (2002) Using breath tests wisely in a gastroenterology practice: an evidence-based review of indications and pittfalls in interpretation. Am J Gastroenterol 97:1113-1126

35. Shen M, Fan D, Zang Y, Chen Y, Zhu K, Cai Z, Liu Y, Sun X, Liu J, Gong J (2016) Neuroprotective effects of methane-rich saline on experimental acute carbon monoxide toxicity. J Neurol Sci 369:361-367. https://doi.org/10.1016/.j.jns.2016.08.055

36. Song K, Zhang M, Hu J, Liu Y, Liu Y, Wang Y, Ma X (2015) Methane-rich saline attenuates ischemia/reperfusion injury of abdominal skin flaps in rats via regulating apoptosis level. BMC Surg 15:92. https://doi.org/10.1186/s12893-015-0075-4

37. Strifler G, Tuboly E, Szél E, Kaszonyi E, Cao C, Kaszaki J, Mészáros A, Boros M, Hartmann P (2016) Inhaled methane limits the mitochondrial electron transport chain dysfunction during experimental liver ischemia-reperfusion injury. PLoS One 11(1):e0146363. https://doi.org/10.1371/journal.pone.0146363

38. Sun A, Wang W, Ye X, Wang Y, Yang X, Ye Z, Sun X, Zhang C (2017) Protective effects of methane-rich saline on rats with lipopolysaccharide-induced acute lung injury. Oxidative Med Cell Longev 2017:7430193. https://doi.org/10.1155/ 2017/7430193

39. Swanson KV, Deng M, Ting JP (2019) The NLRP3 inflammasome: molecular activation and regulation to therapeutics. Nat Rev Immunol 19(8):477-489. https://doi.org/10.1038/s41577-019-0165-0

40. Szűcs S, Bari G, Ugocsai M, Lashkarivand RA, Lajkó N, Mohácsi Á, Szabó A, Kaszaki J, Boros M, Érces D, Varga G (2019) Detection of intestinal tissue perfusion by real-time breath methane analysis in rat and pig models of mesenteric circulatory distress. Crit Care Med 47(5):e403-e411. https://doi.org/10.1097/CCM.0000000000003659 
41. Triantafyllou K, Chang C, Pimentel M (2013) Methanogens, methane and gastrointestinal motility. J Neurogastroenterol Motil 20:31-40. https://doi.org/10.5056/jnm.2014.20.1.31

42. Tuboly E, Mészáros A, Boros M (2014). Nonbacterial biotic methanogenesis, possible mechanisms and significance. In: GB Ghokilandi (ed) Methanogenesis: biochemistry, ecological functions, natural and engineered environments pp 19-50. Nova Science Publishers, Inc. NY, USA

43. Tuboly E, Molnár R, Tőkés T, Turányi RN, Hartmann P, Mészáros AT, Strifler G, Földesi I, Siska A, Szabó A, Mohácsi Á, Szabó G, Boros M (2017) Excessive alcohol consumption induces methane production in humans and rats. Sci Rep 7(1): 7329. https://doi.org/10.1038/s41598-017-07637-3

44. Wang L, Yao Y, He R, Meng Y, Li N, Zhang D, Xu J, Chen O, Cui J, Bian J, Zhang Y, Chen G, Deng X (2017) Methane ameliorates spinal cord ischaemia-reperfusion injury in rats: antioxidant, anti-inflammatory and anti-apoptotic activity mediated by Nrf2 activation. Free Rad Biol Med 103:69-89. https://doi.org/10.1016/j.freeradbiomed.2016.12.014

45. Wang R, Sun Q, Xia F, Chen Z, Wu J, Zhang Y, Xu J, Liu L (2017) Methane rescues retinal ganglion cells and limits retinal mitochondrial dysfunction following optic nerve crush. Exp Eye Res 159:49-57. https://doi.org/10.1016/j.exer.2017.03.008

46. Wang W, Huang X, Li J, Sun A, Yu J, Xie N, Xi Y, Ye X (2017) Methane suppresses microglial activation related to oxidative, inflammatory, and apoptotic injury during spinal cord injury in rats. Oxidative Med Cell Longev 2017:2190897. https://doi.org/10.1155/2017/2190897

47. Wang G, Xu B, Shi F, Du M, Li Y, Y U T, Chen L (2019) Protective effect of methane-rich saline on acetic acid-induced ulcerative colitis via blocking the TLR4/NF-KB/MAPK pathway and promoting IL-10/JAK1/STAT3-mediated antiinflammatory response. Oxidative Med Cell Longev 2019:7850324. https://doi.org/10.1155/2019/7850324

48. Wishkerman A, Greiner S, Ghyczy M, Boros M, Rausch T, Lenhart K, Keppler F (2011) Enhanced formation of methane in plant cell cultures by inhibition of cythochrome c oxidase. Plant Cel Environ 34:457-464

49. Wongnate T, Ragsdale SW (2015) The reaction mechanism of methyl-coenzyme M reductase: how an enzyme enforces strict binding order. J Biol Chem 290:9322-9334

50. Wu J, Wang R, Ye Z, Sun X, Chen Z, Xia F, Sun Q, Liu L (2015) Protective effects of methane-rich saline on diabetic retinopathy via anti-inflammation in a streptozotocin-induced diabetic rat model. Biochem Biophys Res Commun 466: 155-161. https://doi.org/10.1016/j.bbrc.2015.08.121

51. Xie Q, Fei M, Fa Z, Wang L, Wang J, Zhang Y, Wang J, Deng X (2017) Methane-rich saline alleviates cerulein-induced acute pancreatitis by inhibiting inflammatory response, oxidative stress and pancreatic apoptosis in mice. Int Immunopharmacol 51:17-24. https://doi.org/10.1016/j.intimp.2017.07.022

52. Xin L, Sun X, Lou S (2016) Effects of methane-rich saline on the capability of one-time exhaustive exercise in male SD rats. PLoS One 11(3):e0150925. https://doi.org/10.1371/journal.pone.0150925

53. Yao Y, Wang L, Jin P, Li N, Meng Y, Wang C, Xu M, Zhang Y, Bian J, Deng X (2017) Methane alleviates carbon tetrachloride induced liver injury in mice: anti-inflammatory action demonstrated by increased PI3K/Akt/GSK-3 $\beta$ mediated IL-10 expression. J Mol Histol 48:301-310. https://doi.org/10.1007/s10735-017-9728-1

54. Ye Z, Chen O, Zhang R, Nakao A, Fan D, Zhang T, Gu Z, Tao H, Sun X (2015) Methane attenuates hepatic ischemia/ reperfusion injury in rats through antiapoptotic, anti-inflammatory, and antioxidative actions. Shock 44:181-187. https:// doi.org/10.1097/SHK.0000000000000385

55. Zhang H, DiBaise JK, Zuccolo A, Kudrna D, Braidotti M, Yu Y, Parameswaran P, Crowell MD, Wing R, Rittmann BE, Krajmalnik-Brown R (2009) Human gut microbiota in obesity and after gastric bypass. Proc Natl Acad Sci U S A 106: 2365-2370. https://doi.org/10.1073/pnas.0812600106

56. Zhang X, Li N, Shao H, Meng Y, Wang L, Wu Q, Yao Y, Li J, Bian J, Zhang Y, Deng X (2016) Methane limit LPS-induced NF-KB/MAPKs signal in macrophages and suppress immune response in mice by enhancing PI3K/AKT/GSK-3ß-mediated IL-10 expression. Sci Rep 6:29359. https://doi.org/10.1038/srep29359

57. Zhang B, Gao M, Shen J, He D (2017) Inhaled methane protects rats against neurological dysfunction induced by cerebral ischemia and reperfusion injury: PI3K/Akt/HO-1 pathway involved. Arch Med Res 48:520-525. https://doi.org/10. 1016/j.arcmed.2018.01.001

58. Zhang D, Li N, Wang Y, Lu W, Zhang Y, Chen Y, Deng X, Yu X (2019) Methane ameliorates post-operative cognitive dysfunction by inhibiting microglia NF-KB/MAPKs pathway and promoting IL-10 expression in aged mice. Int Immunopharmacol 71:52-60. https://doi.org/10.1016/j.intimp.2019.03.003

59. Zhou SZ, Zhou YL, Ji F, Li HL, Lv H, Zhang Y, Xu H (2018) Analgesic effect of methane rich saline in a rat model of chronic inflammatory pain. Neurochem Res 43:869-877. https://doi.org/10.1007/s11064-018-2490-2

\section{Publisher's Note}

Springer Nature remains neutral with regard to jurisdictional claims in published maps and institutional affiliations. 